Sumadi · T. Nurmala

\title{
Pengaruh invigorasi benih hanjeli (Coix lacryma-jobi L.) terdeteriorasi terhadap mutu fisiologis serta dampaknya terhadap hasil
}

\section{The effect of invigoration deteriorated job's tears seeds to physiological quality and its impact on yield}

\author{
Diterima : 22 Agustus 2019/Disetujui : 27 Desember 2019 / Dipublikasikan : 31 Desember 2019 \\ CDepartment of Crop Science, Padjadjaran University
}

\begin{abstract}
Seed invigoration is an effort to improve the quality of deteriorated seeds by various growth regulators, pesticides enriched with hormones, and biological agents. The objective of the study was to determine the appropriate substance for quality enhancement of deteriorated job's tears seeds and their impact on yield. High seed quality is one of the factors affected growth and yield. The experiment was conducted from November 2015 to June 2016 at the Experimental Stations, Faculty of Agriculture, University of Padjadjaran, Jatinangor, Sumedang. Experiments designed by split plot design that replicated three times. The main plot was two levels of deterioration of seeds, there were medium vigor seeds (germination capacity (GC) $\pm 80 \%$ ); deteriorated seeds or low vigor (GC $\pm 50 \%)$. Subplot consisted of five levels of invigoration treatment, there were control; soaking the seeds in $70^{\circ} \mathrm{C}$ hot water for 30 minutes; coating of seeds with thiametoxam; soaking the seeds in instant gibberellic acid (GA) and coating the seeds with Trichoderma compost solution. The results of the experiment showed that there was an interaction effect between the level of seed deterioration and seed invigoration as measured by seedling emergence potential, but no affected on yield components and seed weight per plant. Invigoration with GA and Trichoderma able to vigour increased of deteriorated seeds
\end{abstract}

Keywords : Deteriorated seed $\cdot \mathrm{Job}^{\prime}$ s tears . Invigoration

Sari. Invigorasi benih merupakan upaya perbaikan mutu benih terdeteriorasi dengan berbagai zat pengatur tumbuh, pestisida yang diperkaya dengan hormon tumbuh, dan agen hayati. Tujuan penelitian adalah untuk menentukan substansi yang tepat bagi invigorasi benih hanjeli terdeteriorasi serta dampaknya terhadap hasil biji Benih bermutu tinggi merupakan salah faktor yang mempengaruhi pertumbuhan dan hasil tanaman.Percobaan pot dilaksanakan mulai bulan November 2015 sampai dengan Juni 2016 di Kebun Percobaan Fakultas Pertanian, Universitas Padjadjaran, kampus Jatinangor, Sumedang. Percobaan dirancang dengan Rancangan Petak Terbagi diulang tiga kali. Petak utama adalah dua tingkat vigor benih, yaitu benih bervigor sedang (daya berkecambah $\pm 80 \%$ ) dan benih terdeteriorasi (bervigor rendah yang daya berkecambahnya $\pm 50 \%$ ). Anak petak berupa lima taraf perlakuan invigorasi, yaitu: kontrol; perendaman benih dalam air panas $70^{\circ} \mathrm{C}$ selama 30 menit; pelapisan benih dengan zat thiametoksam; perendaman benih dalam larutan asam giberelat instan dan pelapisan benih dengan larutan kompos Trichoderma. Hasil percobaan menunjukkan terdapat saling keterkaitan antara tingkat deteriorasi benih dengan invigorasi benih sebagaimana terukur pada daya tumbuh, tetapi tidak berpengaruh terhadap komponen hasil dan bobot biji per tanaman. Invigorasi dengan asam giberelat instan dan kompos Trichoderma mampu meningkatkan vigor benih terdeteriorasi sebesar $47,36-60,52 \%$

Kata kunci: Deteriorasi • Coix lacryma-jobi L. • Invigorasi

\footnotetext{
Dikomunikasikan oleh Anne Nuraini dan Devi Rusmin

Sumadi $^{1} \cdot$ T. Nurmala $^{1}$

1Dosen PS Agroteknologi FakultasPertanian UNPAD

Korespondensi : sumadi@unpad.ac.id
} 


\section{Pendahuluan}

Hanjeli (Coix lacryma-jobi L.) adalah salah satu jenis tanaman serealia potensial yang memiliki kandungan karbohidrat tinggi, protein, lemak nabati, kalsium, dan senyawa lain yang berguna dalam mengobati berbagai macam penyakit (Nurmala, 2010; Ha et al., 2010). Dengan demikian peranannya tidak saja untuk keperluan diversifikasi pangan, tetapi juga sebagai bahan baku untuk keperluan medis. Keunggulan lainnya, hanjeli mampu tumbuh berkembang pada kondisi lingkungan yang kurang menguntungkan, sehingga banyak ditanam pada lahan marginal. Sampai sekarang penyediaan benihnya belum dikelola dengan baik sebagaimana benih-benih tanaman pangan lain, sehingga saat akan ditanam mutunya tidak terjamin.

Peningkatan vigor dan viabilitas benih terdeteriorasi dapat dilakukan dengan teknik invigorasi benih (seed enhancements). Teknik invigorasi yang umum dilakukan antara lain : seed treatment, seed coating, atau pun perendaman benih dengan larutan kimia sebelum penanaman. Bahan kimia yang biasa digunakan dapat berupa zat pengatur tumbuh, fungisida, insektisida, nutrisi mikro, dan bahan lainnya yang langsung diberikan pada benih (Copeland dan McDonald, 2004; Cox et al., 2007; Cox et al., 2008). Bahkan dapat juga berupa mikroba antagonis anti patogen benih atau biological seed treatment (Copeland dan McDonald, 2004; Agustiansyah et al., 2010; Ilyas, 2012),salah satunya dengan Trichoderma spp.

Invigorasi benih dengan merendam benih dalam larutan asam giberelat mampu meningkatkan daya berkecambah beberapa benih dengan berbagai tingkat deteriorasi (BalagueraLópez et al., 2009; Hedden dan Thomas (2012)). Konsentrasi yang digunakan bergantung pada jenis dan tingkat deteriorasi benih. Asam giberelat dapat juga memperbaiki pertumbuhan dan perkembangan tanaman, baik tumbuh vegetatif maupun reproduktif (Salisbury and Ross, 1992). Selain itu, dapat juga menggunakan insektisida thiametoksam yang diperkaya hormon tumbuh, sehingga kecambah yang dihasilkan lebih vigor (Wilde et al., 2004). Demikian juga halnya dengan Trichoderma spp yang mampu meningkatkan vigor benih (Harman, 2006). Beberapa hasil penelitian menyimpulkan bahwa Trichoderma spp mampu memperbaiki perkecambahan dan pertumbuhan akar tanaman (Harman, 2006; Schuster and Schmoll, 2010; Islam et al., 2012).

Perendaman benih dengan air, insektisida berbahan aktif thiametoksam, dan agen hayati juga juga dapat mempercepat perkecambahan (Cox et al., 2007; Cox et al., 2008; Sumadi et al., 2011; Sumadi et al., 2012). Beberapa hasil penelitian pada tanaman kedelai memperlihatkan pengaruh yang tidak konsisten terhadap hasil biji (Sumadi et al., 2015). Informasi invigorasi benih hanjeli dengan bahan kimia maupun agen hayati belum banyak ditemukan. Walaupun demikian salah satu senyawa kimia dan agen hayati diduga mampu memperbaiki viabilitas, vigor benih, dan hasil tanaman hanjeli.

\section{Bahan dan Metode}

Percobaan dilaksanakan pada bulan November 2015 - Juli 2016 di Laboratorium Teknologi Benih dan Kebun Percobaan Fakultas Pertanian Unpad, kampus Jatinangor, Sumedang. Lokasi penelitian berada pada ketinggian $\pm 750 \mathrm{~m} \mathrm{dpl}$ yang memiliki tipe iklim C3 berdasarkan klasifikasi Oldeman.

Bahan yang digunakan meliputi benih hanjeli pulut aksesi 26 bervigor sedang (DB \pm $80 \%$ ) dan bervigor rendah (DB $\pm 52 \%$ ) koleksi Laboratorium Pemuliaan Tanaman, Fakultas Pertanian, UNPAD, masing-masing telah mengalami penyimpanan 3 dan 6 bulan, tanah Inceptisols, kertas merang, polybag diameter 25 $\mathrm{cm}$, pupuk kandang domba, Urea, $\mathrm{SP} 36, \mathrm{KCl}$, giberelin instan, air panas $\left(70{ }^{\circ} \mathrm{C}\right)$, kompos Tricho G, dan insektisida tiametoksam. Adapun alat -alat yang digunakan terdiri dari hand sprayer, germinator, bambu penyangga, serta peralatan untuk keperluan budidaya tanaman.

Penelitian merupakan percobaan pot di lapangan tanpa naungan, dirancang dalam Rancangan Petak Terbagi yang diulang tiga kali. Setiap satuan percobaan terdapat empat polybag masing-masing untuk keperluan pengukuran vigor benih, hasil, dan tanaman cadangan. Petak Utama adalah tingkat deteriorasi benih (D) terdiri dua taraf, yaitu: benih bervigor sedang $\left(\mathrm{d}_{1}\right)$ (daya berkecambah $\pm 80 \%$ ) dan vigor rendah $\left(\mathrm{d}_{2}\right)$ (daya berkecambah $\pm 50 \%$ ). Anak petak adalah perlakuan invigorasi (I), terdiri lima taraf, yaitu tanpa invigorasi (io), perendaman dalam air panas $\left(\begin{array}{lll} \pm & \mathrm{C}\end{array}\right)\left(\mathrm{i}_{1}\right)$, 
thiametoksam sesuai ketentuan rekomendasi produsen ( $3.3 \mathrm{~mL} \mathrm{Kg}^{-1}$ benih) (i $\left.\mathrm{i}_{2}\right), 25 \mathrm{ppm} \mathrm{GA} 3$ (i3), $2 \mathrm{~g} / 100$ butir benih kompos Trichoderma (kerapatan spora $1012 \mathrm{CFU} / \mathrm{g}$ (i4). Invigorasi dilakukan sesuai perlakuan masing-masing \pm 1 jam sebelum tanam.

Pemeliharaan meliputi pemupukan, penyiraman, pengendalian organisme pengganggu, dan memasang bambu penyangga agar tanaman tidak rebah akibat angin. Pemberian pupuk kandang domba dosis $100 \mathrm{~g} /$ polybag dilakukan satu minggu sebelum tanam. Pupuk anorganik yang diberikan adalah urea $300 \mathrm{~kg} / \mathrm{ha}$, SP-36 200 $\mathrm{kg} / \mathrm{ha}$, dan $\mathrm{KCl} 100 \mathrm{~kg} / \mathrm{ha}$. Pupuk urea diberikan dua kali, yaitu saat tanam dan saat vegetatif akhir.

Data penunjang meliputi kesuburan tanah awal sebelum percobaan, organisme yang menyerang tanaman, curah hujan, suhu, kelembaban udara pada lingkungan tempat percobaan, daya berkecambah, dan bobot 100 butir benih Daya berkecambah awal diperoleh dengan metode Uji Kertas Digulung Plastik (UKDP) di germinator.

Variabel respons percobaan meliputi vigor benih diamati 2 - 3 minggu, yang diukur dengan menghitung kecambah normal yang tumbuh di media tanam langsung di lapangan, komponen hasil, hasil tanaman, dan Indeks Panen. Panen dilakukan mulai 180 hari setelah tanam (hst) 190 hst.

\section{Hasil dan Pembahasan}

Kesuburan media tumbuh, temperatur, curah hujan dan kelembaban. Karakteristik kimia tanah bersifat agak masam dengan $\mathrm{pH} \mathrm{H}_{2} \mathrm{O}$ sebesar 5,88 dan $\mathrm{pH} \mathrm{KCl}$ sebesar 4,60, tetapi masih sesuai dengan syarat tumbuh tanaman hanjeli (Nurmala dan Irwan, 2007). Kandungan $\mathrm{P}_{2} \mathrm{O}_{5}$ dan $\mathrm{K}_{2} \mathrm{O}$ dalam tanah termasuk kategori rendah dan sedang. Oleh karena itu, masih diperlukan pemberian pupuk Urea, TSP dan $\mathrm{KCl}$.

Temperatur udara dan kelembaban relatif rata-rata selama percobaan masing-masing sebesar $23{ }^{\circ} \mathrm{C}$ dengan suhu maksimum dan minimum masing-masing sebesar $28{ }^{\circ} \mathrm{C}$ dan $21,9^{\circ} \mathrm{C}$. Ratarata kelembaban nisbi harian berkisar antara 88 91\%. Curah hujan rata-rata antara $94-389,5$ $\mathrm{mm} /$ bulan.

Organisme pengganggu tanaman. Serangan belalang (Valanga nigricornis Burm.) dan hama ulat penggulung daun (Cnaphalocrosis medinalis) mulai terlihat pada 4 minggu setelah tanam (mst). Intensitas serangan belalang mencapai $18 \%$ yang menyebabkan seluruh daun habis, namun bisa diatasi dengan mengganti dengan tanaman cadangan. Penyakit hawar daun merupakan jenis penyakit yang menyerang tanaman hanjeli selama percobaan, namun intensitas serangan dikategorikan ringan.

Viabilitas dan Bobot 100 butir Sebelum Percobaan. Viabilitas dan ukuran benih sebelum percobaan diukur dengan melakukan uji daya berkecambah dan menimbang bobot 100 butir (Tabel 1).

Tabel 1. Rata-rata daya berkecambah dan bobot 100 butir benih sebelum percobaan.

\begin{tabular}{llcc}
\hline No & Asal Benih & $\begin{array}{c}\text { Daya } \\
\text { Berkecam } \\
\text { bah }(\%)\end{array}$ & $\begin{array}{c}\text { Bobot 100 } \\
\text { butir }(\mathrm{g})\end{array}$ \\
\hline 1 & $\begin{array}{l}\text { Benih telah disimpan } \\
\text { selama 3 bulan }\left(\mathrm{d}_{1}\right)\end{array}$ & $80-85$ & 11,77 \\
2 & $\begin{array}{l}\text { Benih telah tersimpan } \\
\text { lebih dari 6 bulan }\left(\mathrm{d}_{2}\right)\end{array}$ & $50-60$ & 10,70 \\
\hline \multicolumn{3}{l}{ Sumber :Laboratorium Teknologi Benih UNPAD }
\end{tabular}

Sumber :Laboratorium Teknologi Benih UNPAD

Hasil uji daya berkecambah awal menunjukkan bahwa benih yang telah disimpan tiga bulan maupun lebih dari enam bulan mengalami kemunduran. Artinya, kedua kelompok benih sudah mengalami deteriorasi.

Vigor Benih Setelah Invigorasi. Salah satu tolok ukur vigor benih adalah kemampuan kecambah yang muncul (seedling emergence) di atas permukaan media tumbuh. Hasil analisis ragam menununjukkan adanya pengaruh interaksi antara mutu benih dan invigorasi terhadap vigor benih yang ditunjukkan dengan persentase daya berkecambah benih (Tabel 2).

Tabel 2. Pengaruh invigorasi benih hanjeli terdeteriorasi terhadap daya tumbuh (\%).

\begin{tabular}{cccccc}
\hline Mutu & \multicolumn{5}{c}{ Invigorasi } \\
\cline { 2 - 6 } Benih & $\mathrm{i}_{0}$ & $\mathrm{i}_{1}$ & $\mathrm{i}_{2}$ & $\mathrm{i}_{3}$ & $\mathrm{i}_{4}$ \\
\hline \multirow{2}{*}{$\mathrm{d}_{1}$} & $90,667 \mathrm{~b}$ & $90,667 \mathrm{~b}$ & $77,333 \mathrm{~b}$ & $80,000 \mathrm{a}$ & $92,000 \mathrm{~b}$ \\
& $\mathrm{~B}$ & $\mathrm{~B}$ & $\mathrm{~A}$ & $\mathrm{~A}$ & $\mathrm{~B}$ \\
$\mathrm{~d}_{2}$ & $50,667 \mathrm{a}$ & 25,333 a & $45,333 \mathrm{a}$ & 81,333 a & $74,667 \mathrm{a}$ \\
& $\mathrm{B}$ & $\mathrm{A}$ & $\mathrm{B}$ & $\mathrm{C}$ & $\mathrm{C}$ \\
\hline
\end{tabular}

Keterangan: Nilai rata - rata yang diikuti dengan huruf yang sama (huruf kecil arah vertikal dan huruf besar arah horizontal) menunjukkan hasil tidak berbeda nyata menurut uji duncan pada taraf nyata $5 \%$

Invigorasi benih dengan GA3 dan kompos Trichoderma mampu meningkatkan persentase 
daya tumbuh benih terdeteriorasi yang ditanam pada media tanah. Hal ini sejalan sebagaimana dikemukakan Harman (2006), Schuster and Schmoll (2010), dan Shukla et al. (2014), bahwa Trichoderma spp selain sebagai mikroba antipatogen, juga diduga mensintesis senyawa yang meningkatkan daya tahan kecambah terhadap cekaman abiotik. Sebaliknya bagi benih terdeteriorasi yang direndam air panas, penurunan vigor terjadi secara nyata. Hal ini diduga perendaman benih terdeteriorasi dengan air panas menyebabkan kerusakan membran yang semakin serius. Kerusakan membran menyebabkan kebocoran bahan organik dari dalam benih (Copeland and McDonald, 2004). Beberapa hasil percobaan membuktikan bahwa tingkat kebocoran benih terdeteriorasi sebagaimana terukur dengan nilai Daya Hantar Listrik (DHL) lebih tinggi dibandingkan DHL air redaman benih bervigor tinggi (Sumadi et al., 2016). Untuk menghindari kerusakan membran benih akibat perendaman, invigorasi benih dapat dilakukan dengan metoda priming atau osmoconditioning.

Bobot 100 butir, Jumlah Biji, Bobot Biji dan Indeks Panen. Hasil analisis statistik menunjukkan bahwa dan tingkat vigor benih dan perlakuan invigorasi tidak berpengaruh nyata terhadap komponen hasil dan indeks panen (Tabel 3), dan hanya berpengaruh pada fase perkecambahan (Tabel 1). Hal ini berarti pertumbuhan dan perkembangan tanaman setelah fase kecambah atau vegetatif awal (2 - 3 mst) dipengaruhi tingkat kesuburan media tumbuh. Sebagaimana percobaan Sumadi et al. (2015) pada tanaman kedelai, pengaruh pelapisan benih hanya sampai fase vegetatif awal, sedangkan pertumbuhan selanjutnya bergantung pada pasokan nutrisi.

Hal yang menarik dari data komponen hasil dan hasil biji per tanaman adalah antara tanaman asal benih bervigor rendah dengan bervigor sedang tidak berbeda nyata. Dengan demikian, pengaruh kualitas benih hanya berpengaruh pada populasi tanaman per satuan luas, sedangkan daya hasil per tanaman tidak berbeda. Walaupun demikian masih perlu pengkajian yang terus menerus yang menyimpulkan bahwa kualitas benih hanya berpengaruh terhadap populasi tanaman per satuan luas, sehingga produktivitas tanaman per hektar bagi tanaman asal benih bervigor rendah lebih kecil dibandingkan dengan tanaman asal benih bervigor tinggi.
Tabel 3. Pengaruh invigorasi benih terdeteriorasi terhadap bobot 100 butir, jumlah biji, bobot biji dan indeks panen.

\begin{tabular}{|c|c|c|c|c|}
\hline Perlakuan & $\begin{array}{c}\text { Bobot } \\
100 \\
\text { butir } \\
\text { (g) }\end{array}$ & $\begin{array}{c}\text { Jumlah } \\
\text { biji/ } \\
\text { tanaman }\end{array}$ & $\begin{array}{c}\text { Bobot } \\
\text { biji/ } \\
\text { tanaman } \\
\text { (g) }\end{array}$ & $\begin{array}{c}\text { Indeks } \\
\text { Panen }\end{array}$ \\
\hline $\mathrm{l}_{1}(\mathrm{I}$ & $9,89 \mathrm{a}$ & $3242,58 \mathrm{a}$ & $346,16 \mathrm{a}$ & $0,40 \mathrm{a}$ \\
\hline o) & 9,29 & $0 \mathrm{a}$ & $6 \mathrm{a}$ & \\
\hline 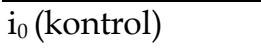 & $9,67 \mathrm{a}$ & 351 & 339, & $7 \mathrm{a}$ \\
\hline ) & $\begin{array}{c}8,89 \text { a } \\
10,12\end{array}$ & $75 \mathrm{a}$ & $321,40 \mathrm{a}$ & $a$ \\
\hline (Thiametoksam) & $\begin{array}{c}\mathrm{a} \\
10,26\end{array}$ & $2937,58 \mathrm{a}$ & $349,08 \mathrm{a}$ & $0,37 \mathrm{a}$ \\
\hline 3 & $\mathrm{a}$ & $2761,46 \mathrm{a}$ & $315,55 \mathrm{a}$ & $0,41 \mathrm{a}$ \\
\hline $\mathrm{i}_{4}$ (Trichoderma) & $9,02 \mathrm{a}$ & $3261,67 \mathrm{a}$ & $317,08 \mathrm{a}$ & $0,55 \mathrm{a}$ \\
\hline \multicolumn{5}{|c|}{$\begin{array}{l}\text { Keterangan: Nilai rata - rata yang diikuti dengan } \\
\text { huruf yang sama (huruf kecil arah vertikal dan huruf } \\
\text { besar arah horizontal) menunjukkan hasil tidak } \\
\text { berbeda nyata menurut uji jarak duncan pada taraf } \\
\text { nyata 5\% }\end{array}$} \\
\hline
\end{tabular}

\section{Kesimpulan dan Saran}

Ada pengaruh interaksi antara tingkat vigor benih dengan macam invigorasi terhadap benih, tetapi tidak berpengaruh terhadap komponen hasil dan hasil biji per tanaman. Larutan GA instan dan kompos Trichoderma mampu meningkatkan vigor benih terdeteriorasi sebesar 47,36 $60,52 \%$. Berdasarkan hasil yang diperoleh, penelitian selanjutnya sebaiknya mengkaji secara mikroskopis peranan Trichoderma dalam perbaikan vigor benih serta aplikasi kompos Trichoderma dengan metoda priming ataupun osmosconditioning.

\section{Ucapan Terima Kasih}

Pada kesempatan ini saya mengucapkan terima kasih kepada Rektor Unpad dan Prof. Tati Nurmala yang menyertakan penulis sebagai tim peneliti hanjeli melalui proyek ALG (Academic Leadership Grant).

\section{Daftar Pustaka}

Agustiansyah, S. Ilyas, Sudarsono dan M. Machmud, 2010. Pengaruh Perlakuan Benih Secara Hayati pada Benih Padi Terinfeksi Xanthomonas oryzae terhadap Mutu benih dan Pertumbuhan Bibit. J. Agron. Indonesia 38 (3) :185-191 
Balaguera-Lopez, H.E., Y.A. Deaquiz, and J.G. Alvarez Herrera. 2009. Obtention of tomato seedlings (Solanum lycopersicum L.) from seeds imbibited in different concentrations of gibberellic acid $\left(\mathrm{GA}_{3}\right)$. Agron. Colomb., 27(1).

Copeland, L.O., and M.B McDonald. 2004. Principles of Seed Science and Technology. Burgess Publ. Co. Minneapolis, Minnesota.

Cox, W.J., E. Shields, and J.H. Cherney. 2008. Planting Date and Seed Treatment Effects on Soybean in the Northeastern United States. J.Agro 100:1662-1665

Cox, W.J., E. Shields, D.J.R. Cherney, and J.H. Cherney. 2007. Seed-Applied Insecticides Inconsistenly Affect Corn Forage in Continuous Corn. J.Agro 99: 1640-1644.

Ha, D.T., T. N. Trung, N.B. Thu, T. V. On, N. H. Nam, C. V. Men, T.T. Phuong, and K. Bae. 2010. Adlay Seed Extract (Coix lacryma-jobi L.) Decreased Adipocyte Differentiation and Increased Glucose Uptake in 3T3-L1 Cells. J. Med .Food, 13 (6): 1331-1339.

Harman, G.E. 2006. Overview of mechanisms and uses of Trichoderma spp. Phytopathology, 96:190-194

Hedden, P., and S.G. Thomas. Gibberellin biosynthesis and its regulation. Biochem J., 444(1):11-25.

Ilyas, S. 2012. Ilmu dan Teknologi Benih. Teori dan hasil-hasil Penelitian. PT. Penerbit IPB Press. Bogor.

Islam R., A. Mukherjee and M. Hossin. 2012. Effect of osmopriming on rice seed germination and seedling growth. J. Bangladesh Agri. Univ., 10(1): 15-20.

Nurmala, T. 2010. Potensi dan Prospek Pengembangan Hanjeli (Coix lacryma-jobi) sebagai Pangan Bergizi Kaya Lemak mendukung Diversifikasi pangan Menuju Ketahanan Pangan Mandiri. Bahan diskusi Jurusan Budidaya Pertanian. Fakultas Pertanian Unpad.
Nurmala, T., dan A.W. Irwan. 2007. Pangan Alternatif. Penerbit Giratuna. Bandung.

Salisbury, F.B and C.W. Ross. 1992. Plant Physiology. $4^{\text {th }}$ ed. Belmont. Wadsworth Pub. Co. Wadsworth biology series

Schuster, A., M. Schmoll. 2010. Biology and biotechnology of Trichoderma. Appl Microbiol Biotechnol., 87:787-799.

Shukla, N., R. Awasthi, L. Rawat, J. Kumar. 2014. Seed biopriming with drought tolerant isolates of Trichoderma harzianum promote growth and drought tolerance in Triticum aestivum. Annals of Applied Biology, 166(2). 166. 10.1111/aab.12160.

Sumadi, A. Nuraini, dan C. Sekaryuniarti. 2011. Pengaruh Seed Coating dengan Insektisida Berbahan Aktif Thiametoksam terhadap Viabilitas, Vigor Benih, Dan Bibit serta dampaknya terhadap Pertumbuhan dan Hasil Tanaman Kedelai. Laporan Penelitian. Faperta Unpad (Tidak dipublikasi).

Sumadi, P.Suryatmana dan D. Sobardini. 2016. Pengaruh aplikasi pelapisan benih terhadap benih terdeteriorasi serta pertumbuhan tanaman kedelai. J. Kultivasi, 15(2): $107-113$

Sumadi, R. Devnita, dan B. Riznati. 2012. Pengaruh Seed Coating dengan Thiametoxam dan Bokashi terhadap Pertumbuhan dan Hasil Benih Kedele. Laporan Penelitian. Program Studi Agroteknologi. Fakultas Pertanian Unpad (Tidak dipublikasi).

Sumadi, P. Suryatmana dan D.Sobardini. 2015. Respons Benih Kedelai Terdeteriorasi terhadap Aplikasi Pelapisan Benih. Prosiding Seminar nasional hasil penelitian Tanaman Aneka Kacang dan Umbiumbian. Balitkabi. Malang.

Wilde, G., K. Roozeboom, M. Claassen, K. Janssen, and M. Witt. 2004. Seed Treatment for Control of Early- Season Pests of Corn and Its Effect on Yield. J. Agric. Urban Entomol. 21(2): 75-85 